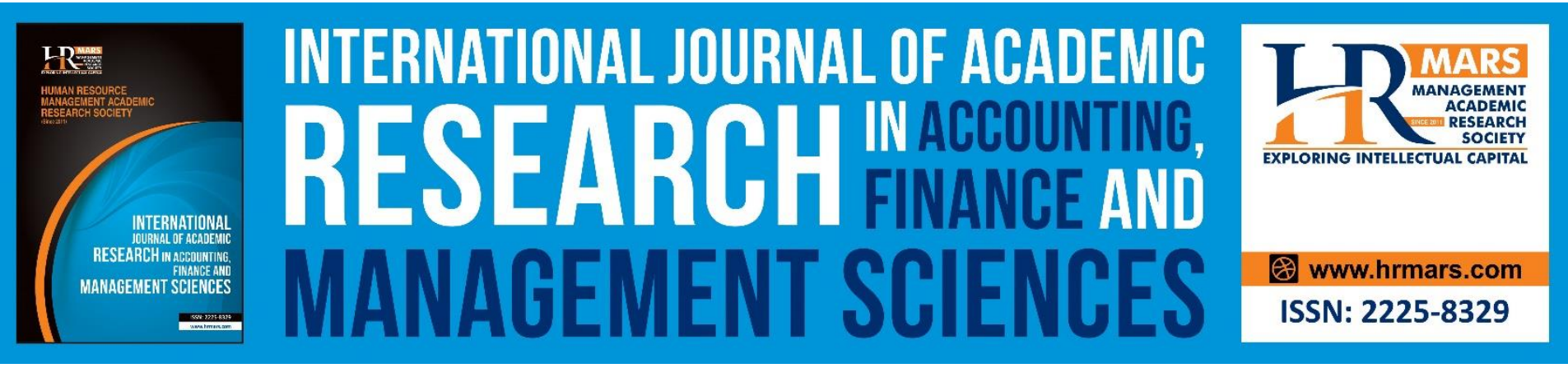

\title{
Influence of Turnaround Strategies on Performance of Firms in the Aviation Industry in Kenya
}

Nderi Alice Nduta, Jared Deya

To Link this Article: http://dx.doi.org/10.6007/IJARAFMS/v10-i3/7705

DOI:10.6007/IJARAFMS/v10-i3/7705

Received: 18 June 2020, Revised: 21 July 2020, Accepted: 25 August 2020

Published Online: 29 September 2020

In-Text Citation: (Nduta, \& Deya, 2020)

To Cite this Article: Nduta, N. A., \& Deya, J. (2020). Influence of Turnaround Strategies on Performance of Firms in the Aviation Industry in Kenya. International Journal of Academic Research in Accounting, Finance and Management Sciences, 10(3), 135-149.

Copyright: (C) 2020 The Author(s)

Published by Human Resource Management Academic Research Society (www.hrmars.com)

This article is published under the Creative Commons Attribution (CC BY 4.0) license. Anyone may reproduce, distribute, translate and create derivative works of this article (for both commercial and non-commercial purposes), subject to full attribution to the original publication and authors. The full terms of this license may be seen

at: $\underline{\text { http://creativecommons.org/licences/by/4.0/legalcode }}$

\section{Vol. 10, No. 3, 2020, Pg. 135 - 149}

Full Terms \& Conditions of access and use can be found at http://hrmars.com/index.php/pages/detail/publication-ethics 


\title{
Influence of Turnaround Strategies on Performance of Firms in the Aviation Industry in Kenya
}

\author{
Nderi Alice Nduta \\ Masters Degree in Strategic Management, Jomo Kenyatta University of Agriculture and Technology \\ (JKUAT), Kenya. \\ Email: alice_nduta@yahoo.com \\ Dr. Jared Deya \\ Lecturer; Jomo Kenyatta University of Agriculture and Technology JKUAT), Kenya. \\ Email: jdeya@jkuat.ac.ke
}

\begin{abstract}
The main drive of this study was to ascertain the influence of turn around strategies on the output of firms in the Aviation sector in Kenya. The specific intents of this research was to find out the influence of Retrenchment plan, Divestment plan, Business process re-engineering strategy and Top management re-organization plan on the output of companies in the Aviation business in Kenya. This study assumed a descriptive research design so as to pronounce the relationship between the predictor variables and the dependent variable and a survey of all the firms was conducted. The target population was all the firms in the Aviation industry in Kenya which are 48 in number. A sample of 3 managers was selected from each company making a total target population of 144 managers from the three levels of management. A sample was determined by use of Krejcie and Morgan formula where the sample size was 105 respondents. The research primary data . The primary data was assembled by use of questionnaires which were developed as per the study objectives and distributed to the respondents. The respondents were given a period of two weeks in order to have enough time to answer the questionnaires, before being collected for cleaning and coding. Data analysis was done by use of SPSS software, version 23, where the collected questionnaires were edited, coded and input into the software for analysis. The data was analyzed for inferential and descriptive statistics where measures of central tendency such as mean and standard deviation were deduced. Tables and bar graphs were used to present the findings. It was found out that the Retrenchment Strategy, Divestment Strategy, Business Process Re-engineering have a positive influence on performance of firms in the Aviation Industry. The study recommends that Aviation firms needs to sale off excess and idle assets to free up capital which can be used to invest elsewhere. On divestment Aviation firms should exit of underperforming market segments saves on financial losses. On BPR, new product development be encouraged as it enlarges the market served. On top
\end{abstract}


INTERNATIONAL JOURNAL OF ACADEMIC RESEARCH IN ACCOUNTING, FINANCE AND

MANAGEMENT SCIENCES

Vol. 10, No. 3, 2020, E-ISSN: 2225-8329 ๑ 2020 HRMARS

management re-organization, the study recommends that hiring experienced top managers should be a priority as it saves on operational mistakes.

Keywords: Turnaround Strategies, Performance, Aviation Industry.

\section{Introduction}

A turnaround state of affairs is one where an organization undergoes deteriorating commercial functioning for an comprehensive duration, so that the functioning points is so small that the existence of the enterprise is endangered but for stern exertions are prepared to advance its operations (Lussier, 2015) . To manage such a situation, a turnaround strategy can be employed. Brandes, Brege \& Brehmer (2015) describes a turnaround scheme as a practice in which organizations pursue to converse the enterprises degeneration and rise corporate performance.

In Thailand, Within a period of three year restructuring performing organizations were viewed to be probable to embrace charge and overhead saving, organization dimension decrease and discarding of less important properties while functioning policies designed at aligning core operations and structures were not expected to be related with prosperous establishments (Robert, Chitnomrath, \& Christopher, 2016). These schemes facilitated pausing the deterioration of the main corporations that were by this time recording substantial losses.

Using a Romanian case, continuing improvement organization can be an effective significant to attain viable commercial functioning enhancement (Herri, Johan, Handika, \& Yulihasri, 2017). The focus in this case was on viable performance upsurge and tactical improvement management. In Germany, growing staff output and trades in the last period have been brought about by high commitment to work and practices that result to corporate change which has enhanced performance outcomes. (Maishanu, 2016).

In India, many firms that are not recording progress have been successfully pulled back from the brink and have firmly been put on the road to recovery. Some of the spectacular recoveries have all had one or more of the following strategies to call upon restoring lender confidence, removing failure team, identifying and motivating performers, downsizing redundant assets and non-performing personnel, creating sustainable business strategy, increasing sales through direct customer contact and improved service and value pricing, maintaining creditor confidence with full timely disclosure of operational and financial results and rapid debt pay down, rebuilding core business and identifying opportunities for sustained growth, focusing the management on key performance issues and creating a successful management team (Ukey \& Krishnarao, 2015).

According to Nnabuife and Onwuzuligbo (2015) in Nigeria, turnaround strategies were aimed towards improving the operational efficiency of an organization that was sick or performing very poorly, if it is in attractive industry. This improvement description suggests that a poor performing organization can be improved, whereas an organization that has broken down cannot be revived. Legal engagements are usually related with organizations which have failed and rarely with organizations whose performance has deteriorated and small firms, whose entry and exit from the market is informal in nature. At any given time, between 20 and 30 percent of most companies in Nigeria are in need of a turnaround (Ollor \& Dagogo, 2015).

National Bank of Kenya undertook turnaround strategies such as competence focused schemes which comprised of discounting or forfeiture of bonuses, downsizings, replacement of top management, combination of excess permanent possessions, shutting down of branch business entities, and sale 
INTERNATIONAL JOURNAL OF ACADEMIC RESEARCH IN ACCOUNTING, FINANCE AND MANAGEMENT SCIENCES

Vol. 10, No. 3, 2020, E-ISSN: 2225-8329 @ 2020 HRMARS

of various business units (Njeru, 2015). Kamunde (2015) on the other hand, established that the bank adopted top management change, stakeholder's involvement and increased efficiency as some of the recovery strategies.

\section{Statement of the Problem}

Turnaround strategies are aimed at steering an organization from the deep state of poor performance to profitability by adopting strategies which are profit motivated and which would push the organization in the right direction. Organizations adopts turnaround strategies due to their need to make profits and pay dividends to the shareholders (Ayiecha \& Katuse, 2015).For an organization to be successful in a given market, the business is expected to choose a set of tactical conduct which equals the size of the business environment in which it operates, and cultivate a skills competency which matches the selected approach (Mokubung, Botha, \& Du Plessis, 2014). Ondimu (2015) noted that improvement scheme is an essential instrument to capture and inverse the bases of economic advantage and commercial flawless of an enterprise as soon as possible. Nderu (2016) argued that improvements in commercial enterprises results to operational efficiency in delivery of services, skillful, liable and responsibility of employees, co-operative leadership and an enhanced corporate conversion with the goals of evading the necessity for shareholder's involvement and winding up (Nderu, 2016).

The Aviation Industry has been faced by numerous challenges in their operations. Some of the challenges faced by the players in this industry includes reduced market, high cost of fuel, record safety, inadequate skilled manpower, internal liberalization of the industry high taxation costs and turbulent environment (Mutema, 2016). A current case which can be looked at present now is the meagre performance of the industry which has continuously made losses half year report of 2014, the industry had a net loss of Sh.258 billion and continued to make losses in the years that followed such as Kshs. 487 Billion losses in the year 2015 and Kshs.534 Billion losses in 2016 (OAG, 2016). However, in the year 2018, the losses reduced to Kshs.428 Billion (OAG, 2018) .Further, the Aviation industry growth rate and its contribution to the Kenya's GDP has been fluctuating with a growth of $5.4 \%, 3.3 \%$ and $3.1 \%$ in the year 2015, 2016 and 2017 respectively (OAG, 2018) For the Industry to realize better output there is a need for improvement plans as argued by Nderu (2016). This study therefore intends to find out some of the turnaround strategies they have adopted and its effect on performance.

\section{Objectives of the Study}

The main focus of this study was to ascertain the influence of turnaround strategies on performance of firms in the Aviation Industry in Kenya. The specific Objectives were;

1. To establish the effect of retrenchment strategies on performance of firms in the Aviation Industry in Kenya.

2. To learn the influence of divestment strategies on performance of firms in the Aviation Industry in Kenya

3. To discover the influence of business process reengineering strategies on performance of firms in the Aviation Industry in Kenya.

4. To determine the influence of top management reorganization strategies on performance of firms in the Aviation Industry in Kenya. 


\section{Theoretical Literature Review \\ Theory of Strategic Orientation}

Schendel and Hofer (1970) proposed the theory to classify improvement schemes into two main categories namely effectiveness focused on and business focused on strategies. The theory argues that a firm can embrace effectiveness focused on plans such as expense reduction strategies and retrenchment when faced with a serious distress that needs efficiency. On the other hand, when a firm is no longer distressed but needs to turnaround a performance situation, it can involve in entrepreneurial oriented strategies where it can divest and venture into uncharted territory. This method encourages a firm to venture into new territories when its strategy is no longer working in its current environment. The theory supports two objectives of the study that is retrenchment and divestment strategies. According to the theory, a firm can adopt divestment strategy as an entrepreneurial oriented strategy when the current strategies are not working in its current territory.

\section{Strategic Leadership Theory}

Boal and Hooijberg (2001) proposed the theory to shade more light on the need for leaders to be strategic and have capacity to learn and be agile depending with the situation that needs change. The theory argues that organizations change and so should the leaders with them. When the firm leaders are not agile enough, they can plunge an organization into more distress. However, visioned leaders, agile leaders and those that are receptive to change can come up with strategic responses to agile situations in a firm.

This theory is applicable to this research as it supports the fourth objective of this study of top management re-organization and it emphasizes that the environmental turbulence can be maintained through strategic leadership. The theory argues that top management is tasked for creating tactical resolutions in the organization which can spearhead turnaround process in the organizations. It is linked to the top management reorganization strategies and its impact on efficiencies of organizations.

\section{Resource Based Theory}

Wernerfelt (1984) proposed the argument of resources as the determinants of a firm's competitive edge over other firms. Presenting valuable and rare resources as important, theory also argues that improving these resources and re- aligning them is the most important determinant of how the firm would compete in the market with other firms. This theory mostly focuses on the Divestment of corporates as an expansion strategy since it is assumed that most many organizations holds pools of resources which are not fully utilized and they can be utilized for diversification (Mahoney \& Pandian, 1992).Organizations with extra resources can divest into other markets by mergers and acquisition or entering the new market and providing unique products.

The theory is therefore relevant to this study as it supports the second objectives of this research which is Divestment strategies by explaining how an organization can use its extra resources which are not fully utilized to diversify to new markets by buying out existing businesses forming mergers or entering new markets and ensuring successful turnaround and good performance. 


\section{Theory of Punctuated Equilibrium}

Tushman and Romanelli's (1985) proposed this theory which explains evolution of a firm based on fluctuations in the surroundings and the need for the organizations to respond accordingly through specific strategies. The theory argues that a firm faces long periods of change followed by revolutionary convergence and changes. When the frame breaking forces between the firm's structures, processes and strategy are high, a firm needs to reengineer its services and re organize itself to cope.Further analysis of the theory argues that a firm can also gain competitive advantage through innovation, diversification, acquisitions and reorganizing its management. The theory mainly supports the third objective of this study of re-organization and reengineering of the firm processes and systems to be able to compete accordingly in the market.-re-engineering.

\section{Conceptual Framework}

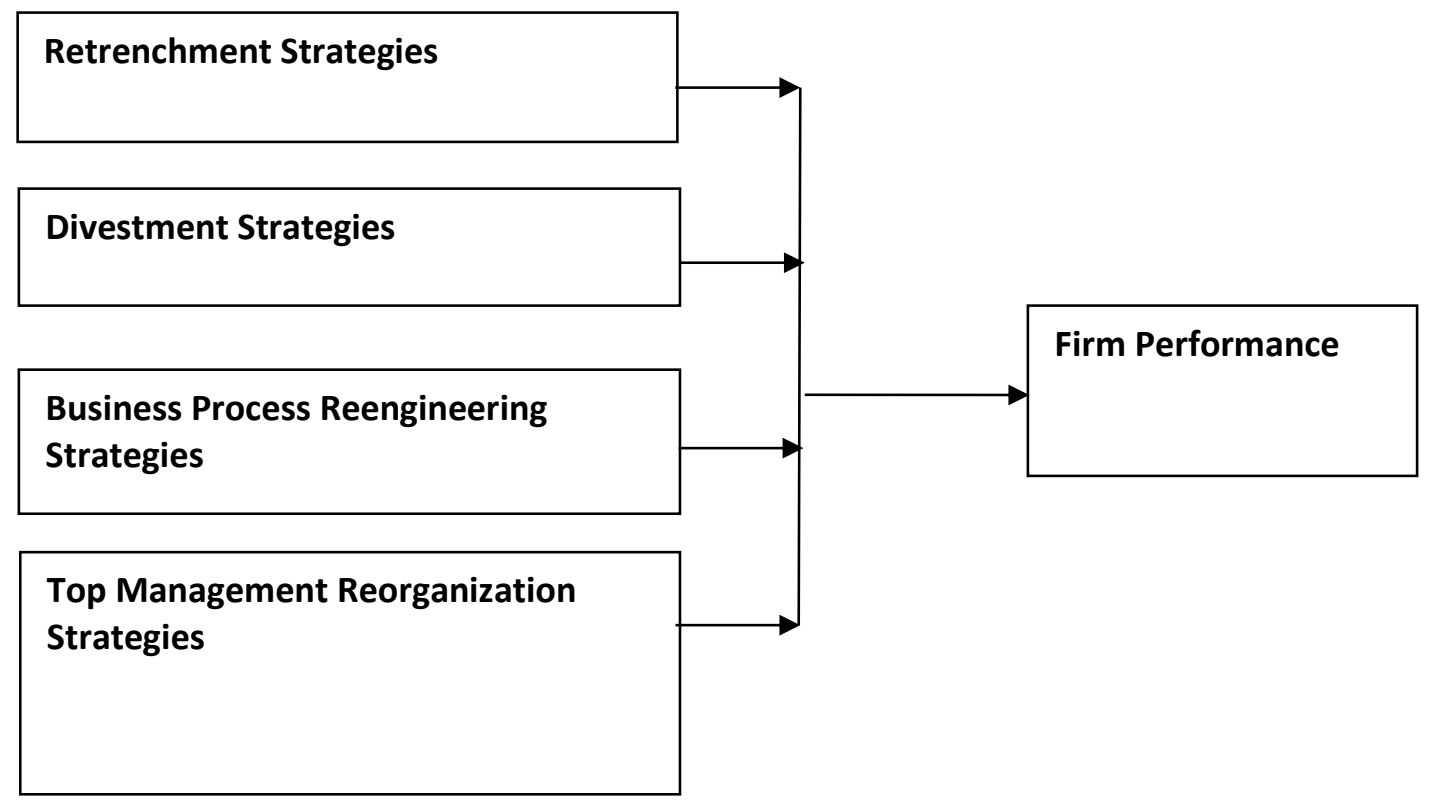

Variables

Dependent variable

Independent

Figure 1 Conceptual Framework

\section{Methodology}

Descriptive research design was used for this study.the study was carried out on all 48 aviation firms in Kenya. The study targeted the employees in top, middle and lower level management in the Aviation Industry for 48 firms, which total to 144 based on the current 2019 human resource statistics. The unit of observation was those employees consisting of managers, assistant managers and supervisors. A sample size of 105 managers was used for the study.both primary data and secondary data was used for the study.Questionnaires were used to collect primary data while secondary data forms were used to assemble secondary data. The data was then analyzed using quantitative analysis which was correlation and regression methods. The study used descriptive statistics such as means, standard deviation and percentages to describe the data. The main methods 
INTERNATIONAL JOURNAL OF ACADEMIC RESEARCH IN ACCOUNTING, FINANCE AND

MANAGEMENT SCIENCES

Vol. 10, No. 3, 2020, E-ISSN: 2225-8329 @ 2020 HRMARS

to test the research questions was correlation and regression and a multiple regression model was used in this study.

The following analytical model was applied for the study;

$\mathrm{Y}=\mathrm{B}_{0}+b_{1} \mathrm{X}_{1}+b_{2} \mathrm{X}_{2}+b_{3} \mathrm{X}_{3}+b_{4} \mathrm{X}_{4}+e$

Where:

$\mathbf{Y}=$ the dependent variable

$\boldsymbol{\beta}_{0}=$ constant

$\boldsymbol{\beta}_{1} \boldsymbol{\beta}_{\mathbf{2}} \boldsymbol{\beta}_{\mathbf{3}} \boldsymbol{\beta}_{\mathbf{4}}=$ Beta Coefficients of independent variables

$\mathbf{X}_{\mathbf{1}}=$ Retrenchment Strategies

$\mathbf{X}_{\mathbf{2}}=$ Divestment Strategies

$\mathbf{X}_{\mathbf{3}}=$ Business Process Reengineering Strategies

$\mathbf{X}_{\mathbf{4}}=$ Top Management Reorganization Strategies

$\boldsymbol{\varepsilon}=$ the error term

\section{Results}

The researcher distributed questionnaires to 105 respondents where 87 were filled and returned for data analysis. The study had a response rate of $83 \%$ which can be credited to the reason that the scholar distributed questionnaires in person and allowed the respondents enough time to fill them. With the aim of determining the reliability of the questionnaire used, the researcher undertook a reliability test by use of Cronbach's alpha. Sekaran and Bougie (2010) affirms that Cronbach's alpha of more than 0.700 authenticates the interior reliability of the questionnaire and this formed the benchmark of this study. From the results presented, Divestment strategy had the highest Cronbach alpha of 0.913 , followed by top management re-organization at 0.911. Business process reengineering strategy had a Cronbach alpha of 0.892 whereas Performance had a Cronbach alpha of 0.835 while retrenchment strategy had the least Cronbach alpha of 0.833. All the variables had a Cronbach alpha value of more than 0.7 denoting that all the variables were reliable.

Table 1 Reliability Test

\begin{tabular}{llll}
\hline Variables & Cronbach's & Cronbach's Alpha Based on & N of Items \\
& Alpha & Standardized Items & \\
\hline Retrenchment strategy & .833 & .835 & 6 \\
Divestment strategy & .913 & .920 & 6 \\
Business process-engineering & .892 & .892 & 6 \\
Top management re-organization & .911 & .913 & 6 \\
Performance & .835 & .835 & 6 \\
\hline
\end{tabular}

Retrenchment Strategy and Performance

Respondents indicated their level of agreement with the statements about effect of retrenchment strategy on performance of aviation industry in Kenya. The results were shown on Table 2 below. 
Table 2: Retrenchment Strategy and Performance

\begin{tabular}{|c|c|c|c|}
\hline Statements on retrenchment strategy & $\mathrm{N}$ & Mean & $\begin{array}{l}\text { Std. } \\
\text { Deviation }\end{array}$ \\
\hline $\begin{array}{l}\text { Getting rid of idle assets frees up cash flows which can be } \\
\text { reinvested in profitable ventures. }\end{array}$ & 87 & 4.71 & .455 \\
\hline Laying off redundant workforce saves on human resource costs. & 87 & 4.56 & .499 \\
\hline Employments by Contract saves on personnel costs. & 87 & 4.70 & .460 \\
\hline $\begin{array}{l}\text { Discontinuing less profitable lines of business creates core } \\
\text { competencies which increases profits. }\end{array}$ & 87 & 4.68 & .470 \\
\hline $\begin{array}{l}\text { Outsourcing services lowers costs of business operations thus } \\
\text { improving the firm's profits. }\end{array}$ & 87 & 4.74 & .444 \\
\hline $\begin{array}{l}\text { Office space downsizing saves on overhead costs hence improving } \\
\text { profits. }\end{array}$ & 87 & 4.69 & .465 \\
\hline Average & & 4.01 & 0.40 \\
\hline
\end{tabular}

From the findings, respondents agreed with the statement that Getting rid of idle assets frees up cash flows which can be reinvested in profitable ventures as shown by a mean of 4.71 .This means that idle assets were tying up funds for the company and therefore companies were disposing off idle and unused assets to be able to use the funds to invest in other business lines. Equally, a mean of 4.56 indicates that the respondents agreed that Laying off redundant workforce saved on human resource costs. What this means is that companies were trying to get rid of unproductive personnel by sacking them off to save on employment costs.

On whether Employments by Contract saves on personnel costs, results shows a positive response as depicted by a mean of 4.70 . This shows that companies prefers employing staff when they have work and this saves them on employment costs during low seasons. Similarly, respondents agreed that discontinuing less profitable lines of business created core competencies which increases profits as shown by a mean of 4.68. This means that aviation firm managers were monitoring the output of each business line to ascertain its contribution in terms of revenue to be able to discontinue loss making business lines. A high mean of 4.74 was found on whether Outsourcing services lowers costs of business operations thus improving the firm's profits. This infers that organizations in the Aviation industry prefers to outsource many services to save on cost of setting up the systems since they are capital intensive and it is cheaper to outsource. On whether Office space downsizing saves on overhead costs hence improving profits positive response was received as depicted by a mean of 4.69.This means that companies were relinquishing excess office space to ensure that they are left with office space which is enough for their operations.

Generally, with an overall mean of 4.01, it shows clearly that Aviation firms in Kenya were applying the retrenchment strategy and this is reinforced by a low standard deviation 
INTERNATIONAL JOURNAL OF ACADEMIC RESEARCH IN ACCOUNTING, FINANCE AND MANAGEMENT SCIENCES

Vol. 10 , No. 3, 2020, E-ISSN: 2225-8329 @ 2020 HRMARS

\section{Divestment strategy and Performance}

Table 3 shows the results that were obtained after analyzing data on the second objective that intended to establish the role of Divestment strategy on performance of firms in the Aviation industry in Kenya

Table 3: Divestment strategy and Performance

\begin{tabular}{|c|c|c|c|}
\hline Statements on Divestment Strategy & $\mathbf{N}$ & Mean & $\begin{array}{l}\text { Std. } \\
\text { Deviation }\end{array}$ \\
\hline $\begin{array}{l}\text { Timely exit of underperforming market segments saves on } \\
\text { financial losses. }\end{array}$ & 87 & 4.80 & .399 \\
\hline $\begin{array}{l}\text { Writing off high maintenance costs tools and machinery leads } \\
\text { to cost savings. }\end{array}$ & 87 & 4.70 & .460 \\
\hline Focus strategy creates competitive advantages for the firm. & 87 & 4.64 & .482 \\
\hline $\begin{array}{l}\text { Sales of business lines reduce exposure to a variety of risks } \\
\text { enabling the firm to concentrate on few revenue lines. }\end{array}$ & 87 & 4.67 & .474 \\
\hline Non-core business activities should be dropped. & 87 & 4.54 & .606 \\
\hline $\begin{array}{l}\text { Having few but performing products and services lines } \\
\text { improves overall profits. }\end{array}$ & 87 & 4.49 & .608 \\
\hline
\end{tabular}

\begin{tabular}{llll}
\hline Average & 4.64 & 0.50
\end{tabular}

With reference to table 3 respondents agreed that the Timely exit of underperforming market segments saves on financial losses as depicted by a mean of 4.80.This means that companies were leaving markets and routes which were proofing to be loss making and concentrating with areas which were making profits. Equally a mean of 4.70 shows that majority of respondents agreed that writing off high maintenance costs tools and machinery leads to cost savings. What this means is that companies were writing off pans and other operational machineries which were having high maintenance cost and producing less output so as to save on costs. This enabled the companies to reduce operation costs.

On whether Focus strategy had created competitive advantages for the firm, results showed a positive response as denoted by a mean of 4.64.This shows that if a company focused on a given market segment, it was able to gain a competitive advantage over its competitors. Similarly, respondents agreed that sales of business lines had reduced the exposure to a variety of risks enabling the firm to concentrate on few revenue lines where a mean of 4.67 determined. This infers that companies were selling off unprofitable ventures which they had invested on but due to loss making, they were selling off to concentrate on profitable revenue lines. Respondents agreed that non-core businesses were being dropped to enable the company's focus on core business where a mean of 4.54 was established. This means Aviation companies were concentrating on their core business and putting their efforts on it to ensure that the business makes profit. Similarly respondents agreed that having few but performing products and services lines improves overall profits as depicted by a mean of 4.49.This implies that Aviation companies were now focusing on few products which were profitable to them and this was ensuring their financial performance improved.

Generally, the findings of divestment as a turnaround strategy indicates that Aviation firms in Kenya were using it to improve on their performance where an overall mean of 4.64 was established. It is 
INTERNATIONAL JOURNAL OF ACADEMIC RESEARCH IN ACCOUNTING, FINANCE AND MANAGEMENT SCIENCES

Vol. 10, No. 3, 2020, E-ISSN: 2225-8329 @ 2020 HRMARS

clear that the respondents agreed that divestment strategy was crucial to the improvement of the performance of Aviation firms in Kenya.

\section{Business Process Re-Engineering Strategy and Performance}

In Table 4 below, the results indicate what was obtained after analyzing data on the third objective that intended to find out the role of Business process re-engineering on functioning of firms in the Aviation industry.

Table 4.Business process re-engineering and Performance

\begin{tabular}{llll}
\hline Statements on Business process re-engineering strategy & $\mathbf{N}$ & Mean & $\begin{array}{l}\text { Std. } \\
\text { Deviation }\end{array}$ \\
\hline $\begin{array}{l}\text { Advanced technology saves on time of undertaking } \\
\text { business operations. }\end{array}$ & 87 & 4.67 & .474 \\
$\begin{array}{l}\text { Advanced technology creates competitiveness. } \\
\text { Innovativeness results into efficient ways of performing }\end{array}$ & 87 & 4.62 & .488 \\
tasks. & & 4.52 & .503 \\
Cost leadership strategies are good for the firms. & 87 & 4.60 & .493 \\
New product development enlarges the market served. & 87 & 4.69 & .465 \\
Decentralizing human resource planning improves & 87 & 4.70 & .460 \\
productivity of workers. & & & \\
\hline Average
\end{tabular}

Average

4.63

0.48

Table 4 indicated that majority of the respondents agreed with the statement that Advanced technology saves on time of undertaking business operations.as reinforced by the mean of 4.67. These results meant that the aviation firms had invested in new technologies in their operations to speed their operations. Equally, respondents agreed with the statement Advanced technology creates competitiveness as shown by the mean of 4.62 . It, therefore, implies that the entities embrace new technologies to assist in sales of their products as this helps to have an upper hand over their competitors. A high mean of 4.52 was established on the question on whether Innovativeness resulted into efficient ways of performing tasks. This was a confirmation that innovation boosted performance of firms.

Similarly, most of the respondents agreed that Cost leadership strategies were good for the firms as evidenced by the mean of 4.60 . These findings indicated that companies are using cost as a tool to compete by offering various price tariffs to appeal to their clients. Also, results revealed that new product development enlarges the market served as shown by a mean of 4.69.This means that having new products ensures that clients have a pool to choose from and this ensures that the company has sales. Equally, respondents agreed that decentralizing human resource planning improved productivity of workers as determined by a mean of 4.70 .

This shows that business process re-engineering is a good strategy being used by companies in the aviation industry to improve productivity of employees. In general, the business process reengineering strategy came out strongly as a popular turnaround strategy being used by Aviation firms in Kenya based on an overall mean of 4.63.

\section{Top Management Re-organization Strategy and Performance}


INTERNATIONAL JOURNAL OF ACADEMIC RESEARCH IN ACCOUNTING, FINANCE AND MANAGEMENT SCIENCES

Vol. 10, No. 3, 2020, E-ISSN: 2225-8329 @ 2020 HRMARS

Table 5 shows the results that were obtained after analyzing data on the fourth objective of inaugurating the role of Top Management re-organization on performance of firms of firms in the Aviation industry in Kenya.

Table 5: Top management re-organization strategy and Performance

\begin{tabular}{|c|c|c|c|}
\hline Statements on top management re-organization & $\mathbf{N}$ & Mean & $\begin{array}{l}\text { Std. } \\
\text { Deviation }\end{array}$ \\
\hline Fixed terms of tenure of top managers creates accountability. & 87 & 4.45 & .500 \\
\hline $\begin{array}{l}\text { Having independent top management from shareholders creates } \\
\text { transparency in the entire firm. }\end{array}$ & 87 & 4.56 & .499 \\
\hline $\begin{array}{l}\text { Board committees' membership rotation improves firm's } \\
\text { governance. }\end{array}$ & 87 & 4.68 & 470 \\
\hline $\begin{array}{l}\text { Having a diverse board composition is valuable to the firm as it } \\
\text { results to a range of wide experience. }\end{array}$ & 87 & 4.74 & 444 \\
\hline Hiring experienced top managers saves on operational mistakes. & 87 & 4.82 & 390 \\
\hline $\begin{array}{l}\text { Top management recruitment through human resource hiring } \\
\text { agencies provides the best management personnel. }\end{array}$ & 87 & 4.63 & 485 \\
\hline Average & & 4.64 & 0.46 \\
\hline
\end{tabular}

With reference to table 5 above, respondents agreed that fixed terms of tenure of top managers creates accountability as shown by a mean of 4.45 . On whether having independent top management from shareholders creates transparency in the entire firm. Respondents agreed with the statement as shown by a mean of 4.56 . What this means is that top management needs to be independent in their decision making to be able to work well without influence from shareholders. A mean of 4.68 was established when respondents were asked whether Board committees' membership rotation improves firm's governance. Results shows an agreement with the statement that having a diverse board composition is valuable to the firm as it results to a range of wide experience where a mean of 4.74 was established. This infers that that companies prefers to have people with experience in various fields to assist the company in decision making which would steer it to profitability. Respondents agreed that hiring experienced top managers saves on operational mistakes as depicted by a mean of 4.82.This means that companies are careful and takes time to ensure they hire experienced and result oriented top managers to enable the company manage its operations profitably. Similarly, a mean of 4.63 was established when respondents were asked whether Top management recruitment through human resource hiring agencies provides the best management personnel.

From the general findings above, it is clear that top management re-organization as a turnaround strategy had a serious implication on the performance of Aviation industry in Kenya, where a general mean of 4.64 was determined, indicating that if correctly applied by Aviation firms, Top management Re-organization can lead to improvement in performance of firms. 


\section{Regression Model}

The study carried out regression analysis to establish the statistical relationship between the independent variables notably $\left(X_{1}\right)$ Retrenchment strategy $\left(X_{2}\right)$ Divestment strategy, $\left(X_{3}\right)$ business process-re-engineering and $\left(\mathrm{X}_{4}\right)$ Top management re-organization and dependent variable $(\mathrm{Y})=$ Performance of aviation firms in Kenya. These results were presented using regression analysis model summary table, Analysis of variance(ANOVA) table and beta co-efficient table.

Table 6 regression Model

\begin{tabular}{|c|c|c|c|c|c|c|}
\hline \multicolumn{7}{|c|}{ Model Summary } \\
\hline Model & $\mathrm{R}$ & R Square & $\begin{array}{l}\text { Adjusted } \\
\text { Square }\end{array}$ & $\mathrm{R}$ & $\begin{array}{l}\text { Std. Error of } \\
\text { the Estimate }\end{array}$ & $\begin{array}{l}\text { Durbin- } \\
\text { Watson }\end{array}$ \\
\hline 1 & $.975^{a}$ & .951 & .757 & & .25373 & 1.827 \\
\hline
\end{tabular}

Table 2 shows $R, R^{2}$ and adjusted $R^{2}$. $R$ is the correlation among the dependent variable and predictors. $R^{2}$ is the coefficient of determinations that describes the extent to which the predictor influence variations in dependent variables while adjusted $R^{2}$ describes the extent of influence between the variables on addition of variables in the equation. The $R$ of 0.975 shows strong correlation among the variables. The $\mathrm{R}^{2}$ of 0.951 shows that $95.1 \%$ of variations in performance is influenced by changes in retrenchment, divestment, BPR and Top management re-organization. This means that other factors not studied accounted for $4.9 \%$ of variations in performance among aviation firms in Kenya. This therefore means that a further research should be conducted to investigate other turnaround strategies which influence the performance of aviation firms in Kenya.

\section{ANOVA Test}

The significance of the model was ascertained by undertaking an analysis of Variance. The results are presented on Table 7

Table 7 ANOVA Test

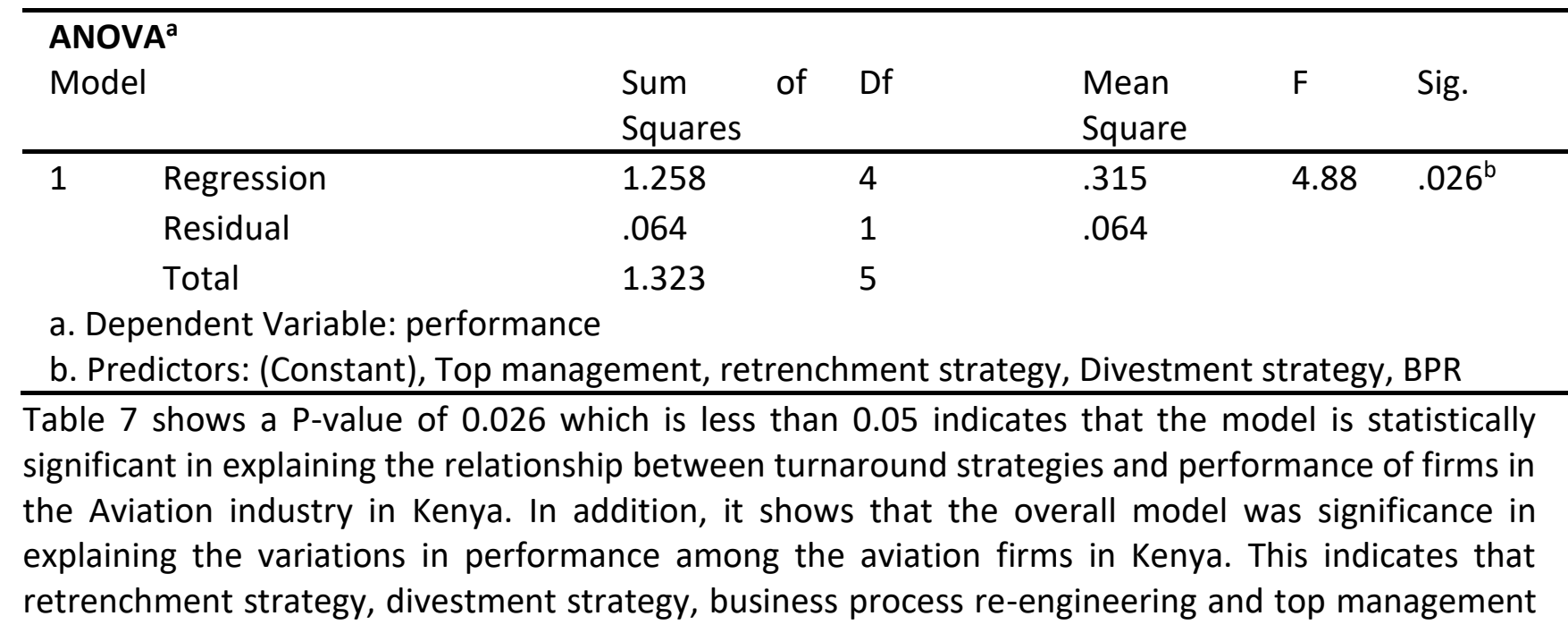


INTERNATIONAL JOURNAL OF ACADEMIC RESEARCH IN ACCOUNTING, FINANCE AND

MANAGEMENT SCIENCES

Vol. 10, No. 3, 2020, E-ISSN: 2225-8329 @ 2020 HRMARS

re-organization had a joint influence on the performance of firms in the Aviation industry in Kenya. Data was processing at $95 \%$ confidence level which means that a statistics of below 0.05 is significant. We thus conclude there is a significant positive relationship between turnaround strategies and performance of Aviation industry in Kenya.

\section{Coefficients}

Table 8 shows the results for coefficients that show the extent and nature of relationship among the variables.

Table 8 Coefficient Model

\begin{tabular}{|c|c|c|c|c|c|c|}
\hline \multirow{2}{*}{\multicolumn{2}{|c|}{ Model }} & \multicolumn{2}{|c|}{$\begin{array}{l}\text { Unstandardized } \\
\text { Coefficients }\end{array}$} & \multirow{2}{*}{$\begin{array}{l}\text { Standardize } \\
\text { d } \\
\text { Coefficients } \\
\text { Beta }\end{array}$} & \multirow[t]{2}{*}{$\mathbf{T}$} & \multirow[t]{2}{*}{ Sig. } \\
\hline & & B & $\begin{array}{l}\text { Std. } \\
\text { Error }\end{array}$ & & & \\
\hline \multirow[t]{5}{*}{1} & (Constant) & -2.736 & 2.835 & & -.965 & .511 \\
\hline & retrenchment strategy & .519 & .277 & .566 & 1.877 & .029 \\
\hline & Divestment strategy & .436 & .171 & .699 & 2.551 & .021 \\
\hline & $\mathrm{BPR}$ & .928 & .309 & .937 & 3.004 & .035 \\
\hline & Top management & .370 & .165 & .553 & 2.245 & .017 \\
\hline
\end{tabular}

Table 8.shows the coefficients of the regression model that were obtained. The regression model is specified as follows:

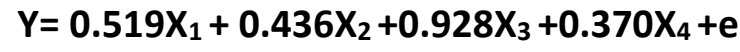

Where $Y$ is the dependent variable, i.e performance of Aviation firms in Kenya, $\mathbf{X}_{\mathbf{1}}$ retrenchment strategy, $\mathbf{X}_{\mathbf{2}}$ Divestment strategy, $\mathbf{X}_{\mathbf{3}}$ Business process re-engineering and $\mathbf{X}_{\mathbf{4}}$ is the top management re-organization. In this case, the constant is negative and therefore insignificant in the equation thus omitted in the equation.

0.519 is the increase in performance of aviation firms in response to a unit increase in retrenchment, 0.436 is the increase in performance of aviation firms in response to a unit increase in Divestment, 0.928 is the increase in performance of aviation firms in response to a unit increase in BPR and 0.370 is a unit increase in performance of Aviation firms in response to a unit increase in Top management re-organization..

Additionally, the P-values on the last column on the Table 8 reveals that all these variables had significant role in performance of Aviation firms in Kenya since the significance statistic were less than 0.05 in all cases. Therefore, it can be inferred that retrenchment strategy, Divestment strategy, Business process re-engineering strategy and top management re-organization strategy have a statistically significant role on performance of Aviation firms in Kenya.

This is consistent with the theoretical arguments and past empirical studies on turnaround strategies where firms experiencing financial downturn employs strategies such as retrenchment strategy, divestment strategy, business process re-engineering and top management re-organization which in turn leads to improvement in performance in the process as the organization retrenches idle assets, 
INTERNATIONAL JOURNAL OF ACADEMIC RESEARCH IN ACCOUNTING, FINANCE AND MANAGEMENT SCIENCES

Vol. 10, No. 3, 2020, E-ISSN: $2225-8329$ ¿ 2020 HRMARS

divests its investments to manage competition, applies business process re-engineering processes which improves business operations and re-organizes its top management to inject new ideas into the business which in turn leads to enhancement in performance of the firm (Mungai \& Bula, 2018)

\section{Conclusion and Recommendations}

The overall goal of this study was to establish the influence of turnaround strategies on the performance of Aviation industry firms in Kenya. The study found out that turn around strategies have a positive effect on the performance of Aviation firms in Kenya.

Inferential statistics revealed that $95.2 \%$ of variations on performance of Aviation firms is explained by retrenchment strategy, divestment strategy, Business process re-engineering strategy and top management re-organization. The model was found to be statistically significant as exhibited by the P-Value of 0.026 statistic for the analysis of variance.

Inferential statistics revealed that retrenchment strategy, divestment strategy, Business process reengineering and top management re-organization have positive effect on financial performance of banks. In addition, all the variables showed a statistically significant relationship with financial performance.

Retrenchment strategy is critical for the good performance of aviation firms in Kenya. Aviation firms needs to sale off excess and idle assets to free up capital which can be used to invest elsewhere. In addition, Aviation firma in Kenya need to outsource services on areas they lack expertise so as to save on excess cost on the company. Further, the study recommends the Aviation firma in Kenya should endeavor to save on costs as much as possible by relinquishing extra office space to save on their operating costs.

On Divestment strategy, the study recommends that the Aviation firms should exit of underperforming market segments saves on financial losses. Further, the study recommends that the aviation industry should write off high maintenance costs tools and machinery to save on costs.in addition, Aviation firms should sale off business lines which are risky and concentrate of lines which are making profits and performing well.

On business process re-engineering, the study recommends that new product development be encouraged as it enlarges the market served. This helps the organization have choices for its customers thus increasing sales. Further, the study recommends that advanced technology be adopted since saves on time of undertaking business operations

On top management re-organization, the study recommends that hiring experienced top managers should be a priority as it saves on operational mistakes. Similarly, the study recommends that aviation firms in Kenya should have a board composition of members with wide range of experience which ensures there is a pool of expertise which steers the company to great heights.

\section{Suggestion for Further Studies}

The research had a general objective of assessing the influence of turnaround strategies on performance of firms in the aviation industry in Kenya. The study has found out turnaround strategies had a major influence on the performance of firms in the aviation industry in Kenya. This research suggests that another research be done to assess the challenges facing the implementation of turnaround strategies among the aviation firms in Kenya. Also, this study concentrated on Aviation 
INTERNATIONAL JOURNAL OF ACADEMIC RESEARCH IN ACCOUNTING, FINANCE AND

MANAGEMENT SCIENCES

Vol. 10, No. 3, 2020, E-ISSN: 2225-8329 @ 2020 HRMARS

firms Kenya, a similar study can be undertaken but with a focus of the manufacturing sector to see if the results may be the same.

\section{References}

Ayiecha, F. O., \& Katuse, P. (2015). Implementing Turnaround Strategy: Effect of Change Management and Management Competence factors. Journal of Business and Management, 3(5),95-103.

Banaszak-Holl, J. (2015). The role of corporate standardization. . Strategic management Journal , 17, 40-57.

Bibeault, D. G. (2015). Corporate Turnaround: How managers turn losers into winners. New York: McGraw-Hill.

Bocken, N. M., de Pauw, I., Bakker, C., \& van der Grinten, B. (2016). Product design and business model strategies for a circular economy. . Journal of Industrial and Production Engineering, , 33(5), 308-320.

Brandes, O., Brege, S., \& Brehmer, P. O. (2015). The strategic importance of supplier relationships in the automotive industry. International Journal of Engineering Business Management, 5-17.

Chang, J. F. (2016). Business process management systems: strategy and implementation. Auerbach Publications.

Daina, O. M., Manana, R. S., \& Gicheru, E. N. (2016). Analysis of turnaround strategies on organization performance: Case of Uchumi supermarket-Kenya. European Journal of Business and Management, 8(31),176-190.

Edwards, J. S. (2015). Business processes and knowledge management. Encyclopedia of Information Science and Technology, 3,4491-4498.

Elmelund, P. C., Klitgaard, M. B., \& Schumacher, G. (2015). What wins public support? Communicating or obfuscating welfare state retrenchment. European Political Science Review, , 7(3), 427-450.

Farah, H. A., Munga, J., \& Mbebe, J. (2018). Influence of competitive strategies on performance of commercial airlines in Kenya: A survey of the airline industry in Kenya. International Academic Journal of Human Resource and Business Administration, , 3(1), 170-189.

Fletcher, A. J. (2017). Applying critical realism in qualitative research: methodology meets method. International Journal of Social Research Methodology, , 20(2), 181-194.

Herri, Johan, A. P., Handika, R. F., \& Yulihasri. (2017). CEO Characteristics and the successful of Turn Around strategy:Evidence from Indonesia. Academy of Strategic Management Journal, 16,(1) 69-80.

Mbandu, A. (2016). Turnaround Strategies and Their Influence on the Financial Performance of Organizations: A Case Study of Uchumi Supermarkets Ltd-Nairobi County Branches. International Journal of Finance and Accounting, , 1(1), 92-107.

Nderu, M. (2016). Influence of Survival Strategies on the Organizational Performance of Kenya Airways. International Journal of Social Sciences and Entrepreneurship, , 1(2), 496-512.

Njeru, S. (2015). Dealing with the past: the youth and post-war recovery in southern Sudan. African Journal on Conflict Resolution., 10(3), 29-50.

OAG. (2018). Office of the Auditor General. Retrieved from Office of the Auditor General Website: https://www.oagkenya.go.ke/ 
INTERNATIONAL JOURNAL OF ACADEMIC RESEARCH IN ACCOUNTING, FINANCE AND MANAGEMENT SCIENCES

Vol. 10 , No. 3, 2020, E-ISSN: 2225-8329 @ 2020 HRMARS

Robert, E., Chitnomrath, T., \& Christopher, T. (2016). Successful turnaround strategy: Thailand evidence. Journal of Accounting in Emerging Economies. , 3 (2) 115-124.

Schoenberg, R., Collier, N., \& Bowman, C. (2016). Strategies for Business Turnaround and Recovery: A Review and Synthesis. European Business Review, 25(3),243-262. 